\title{
Hybridisation in kiwi (Apteryx; Apterygidae) requires taxonomic revision for the Great Spotted Kiwi
}

\author{
Lara D. Shepherd ${ }^{1 *}\left(\mathbb{D}\right.$, Alan J. D. Tennyson ${ }^{1}$, Hugh A. Robertson², Rogan M. Colbourne ${ }^{2}$ and Kristina M. Ramstad ${ }^{3}$
}

\begin{abstract}
Background: Kiwi (Apteryx spp.) are flightless ratites from New Zealand whose numbers and distributions have declined following human arrival. Some of the kiwi species are known to hybridise but the extent of hybridization is unknown.

Methods: We reviewed hybridisation in kiwi (Apteryx spp.) and present new genetic data examining the extent of hybridisation between Rowi (A. rowi) and Little Spotted Kiwi (A. owenii) at Okarito, the location of the only remaining natural population of the threatened Rowi. We also genetically examined the syntype specimens of $A$. haastii Potts, 1872, collected from near Okarito in the 1870s, which have unusual morphologies.
\end{abstract}

Results: We found evidence of recurrent hybridisation between Rowi and Little Spotted Kiwi over the last 150 years, including one F1 hybrid found in the last 15 years, despite Little Spotted Kiwi's likely extinction on the mainland in the 1970s. However, we found little evidence of introgression of Little Spotted Kiwi alleles into the extant Rowi population. The syntype specimens of A. haastii were also found to be hybrids between Little Spotted Kiwi and Rowi.

Conclusions: Our genetic analyses indicate that, although we detected multiple instances of hybridisation between Rowi and Little Spotted Kiwi, it does not appear to be an ongoing threat to Rowi. Because the syntype specimens of A. haastii are hybrids and therefore not representative of the prevailing usage of the name for the Great Spotted Kiwi (A. haastii), we resurrect the nomen oblitum A. maxima Sclater and Hochstetter, 1861 for the large spotted kiwi species.

Keywords: Apteryx, Apteryx haastii, DNA, Hybridisation, Kiwi, Taxonomy

\section{Background}

Hybridisation between species is a common phenomenon in the animal kingdom. Birds show particularly high levels of hybridisation with more than $16 \%$ of bird species known to hybridise with at least one other species in nature, and this number increases to $21 \%$ when hybridisation in captivity is also included (Ottenburghs et al. 2015).

*Correspondence: lara.shepherd@tepapa.govt.nz

${ }^{1}$ Museum of New Zealand Te Papa Tongarewa, Wellington 6011, New Zealand

Full list of author information is available at the end of the article
Hybridisation is a natural part of the evolutionary process and can have positive and negative outcomes (Allendorf et al. 2012; Marques et al. 2019). It can lead to increased genetic diversity, provide a source of adaptive genetic variation (Hedrick 2013) or even result in the formation of a new species (Lamichhaney et al. 2018; Masello et al. 2019). However, hybridisation can also lead to the merging of distinct evolutionary lineages and the genomic extinction of populations or species (Todesco et al. 2016). Rates of hybridisation have greatly increased in response to anthropogenic disturbance (Anderson and Stebbins Jr 1954; Allendorf et al. 2012). Human-induced habitat modification, including disturbance and fragmentation, as well as introductions of organisms outside their

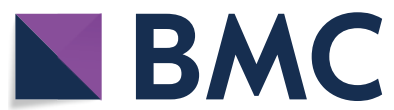

(c) The Author(s) 2021. This article is licensed under a Creative Commons Attribution 4.0 International License, which permits use, sharing, adaptation, distribution and reproduction in any medium or format, as long as you give appropriate credit to the original author(s) and the source, provide a link to the Creative Commons licence, and indicate if changes were made. The images or other third party material in this article are included in the article's Creative Commons licence, unless indicated otherwise in a credit line to the material. If material is not included in the article's Creative Commons licence and your intended use is not permitted by statutory regulation or exceeds the permitted use, you will need to obtain permission directly from the copyright holder. To view a copy of this licence, visit http://creativeco mmons.org/licenses/by/4.0/. The Creative Commons Public Domain Dedication waiver (http://creativecommons.org/publicdomain/ zero/1.0/) applies to the data made available in this article, unless otherwise stated in a credit line to the data. 
native range have all been shown to increase hybridisation (Allendorf et al. 2012; Todesco et al. 2016).

\section{History of kiwi}

Kiwi are flightless ratites that are endemic to New Zealand. Currently five species of kiwi are recognised, and molecular dating has variously estimated that they diverged from one another within the last four million years (Weir et al. 2016), 12 million years (Yonezawa et al. 2017) or 13 million years (Grealey et al. 2017). These species fall into two morphological groups: brown colored kiwi, comprising North Island Brown Kiwi (A. mantelli; Bartlett, 1852), Rowi (A. rowi; Tennyson et al. 2003) and Tokoeka (A. australis; Shaw, 1813); and spotted kiwi, which have barred feathers, comprising Little Spotted Kiwi (Apteryx owenii; Gould, 1847) and Great Spotted Kiwi (A. haastii; Potts, 1872).

From this point forward we use Great Spotted Kiwi to refer to the large spotted kiwi that occurs in the northwest of the South Island, following the prevailing usage (e.g. Gill et al. 2010; Heather et al. 2015; Germano et al. 2018). There is uncertainty over what the name $A$. haastii refers to because the two syntype specimens of $A$. haastii (Canterbury Museum (CM) AV2828 and AV2829; Scofield 2004), which were collected inland from Okarito in 1870-1871, have unusual morphologies with shorter and finer legs than Great Spotted Kiwi (Additional file 1: Table S1). This feature, combined with their collection locations, which are outside the known range of Great Spotted Kiwi and in the vicinity of where recent Little Spotted Kiwi $\times$ Rowi hybrids have been found (see "Hybridisation in kiwi" section below), hints that they may have hybrid ancestry.

Prior to human arrival, kiwi were found across New Zealand. Little Spotted Kiwi were found in both the North and South Islands (Shepherd et al. 2012) but Great Spotted Kiwi were restricted to the northwest of the South Island (Shepherd and Lambert 2008). Brown kiwi were distributed across New Zealand with North Island Brown Kiwi located in the central and northern North Island, Rowi in the southern North Island and central west to northwest South Island, and Tokoeka in the southern and eastern South Island and Stewart Island (Shepherd and Lambert 2008). Therefore, Little Spotted Kiwi previously overlapped in distribution with the other four kiwi species. Great Spotted Kiwi and Rowi were also previously sympatric (Shepherd and Lambert 2008). However, the distributions of the three brown kiwi species apparently had no overlap.

Since human arrival, kiwi numbers and distribution have declined throughout New Zealand, mainly because of predation by introduced mammals (McLennan et al. 1996). The reduced and fragmented distribution of kiwi
(Fig. 1) means that there is currently no natural overlap between any of the species, although Little Spotted Kiwi may have been sympatric with Great Spotted Kiwi, Rowi and Tokoeka within the last 50 years (Shepherd et al. 2012; Colbourne pers. obs.).

\section{Hybridisation in kiwi}

Interspecific kiwi hybrids are known from the wild and a translocated population. In the wild most of the suspected hybrids have been found recently in the vicinity of Okarito (Fig. 1) and are thought to be hybrids between Little Spotted Kiwi and Rowi. These two species are no longer sympatric, with Little Spotted Kiwi last recorded from the South Island in 1978 (Shepherd et al. 2012). Kiwi are long-lived for birds, e.g. the mean life expectancy of adult Little Spotted Kiwi is 45 years (95\% CI 27-83 years; Robertson and Colbourne 2004), thus theoretically early generation hybrids could still be alive at Okarito, despite Little Spotted Kiwi no longer occurring there.

The translocated population of brown kiwi on Kapiti Island has been shown through allozyme analysis to have a hybrid origin, with both Tokoeka and North Island Brown Kiwi ancestry (Herbert and Daugherty 1990). Both of these species, as well as Little Spotted Kiwi, were introduced to Kapiti Island in the early twentieth century (Colbourne 2005 and references therein; Ramstad et al. 2013).

A number of mixed provenance kiwi populations (intraspecific hybrids) have been formed through translocations of genetically distinct lineages within North Island Brown Kiwi (e.g. Ponui Island and Little Barrier Island; Colbourne 2005). Although these lineages are all currently considered to be North Island Brown Kiwi, future taxonomic changes are possible given the level of distinctiveness detected between them (Weir et al. 2016). Mixed provenance North Island Brown Kiwi also occur in captivity, although such populations are being phased out (Barlow 2018).

Hybridisation is a potential threat to kiwi diversity (Ramstad and Dunning 2020) because it could result in the genomic extinction of small populations. For example, the entire natural distribution of Rowi, whose threat status is vulnerable (BirdLife International 2017), is restricted to a single population at Okarito. At the same time, hybrids may harbor genetic variation that is no longer found within current populations, particularly in Little Spotted Kiwi, which suffer from inbreeding depression and extremely low genetic variation owing to a species-wide bottleneck of at most five individuals (Ramstad et al. 2013). The conservation value of such hybrids is controversial-is it better to create a hybrid population that is genetically more diverse than the extant bottlenecked populations 


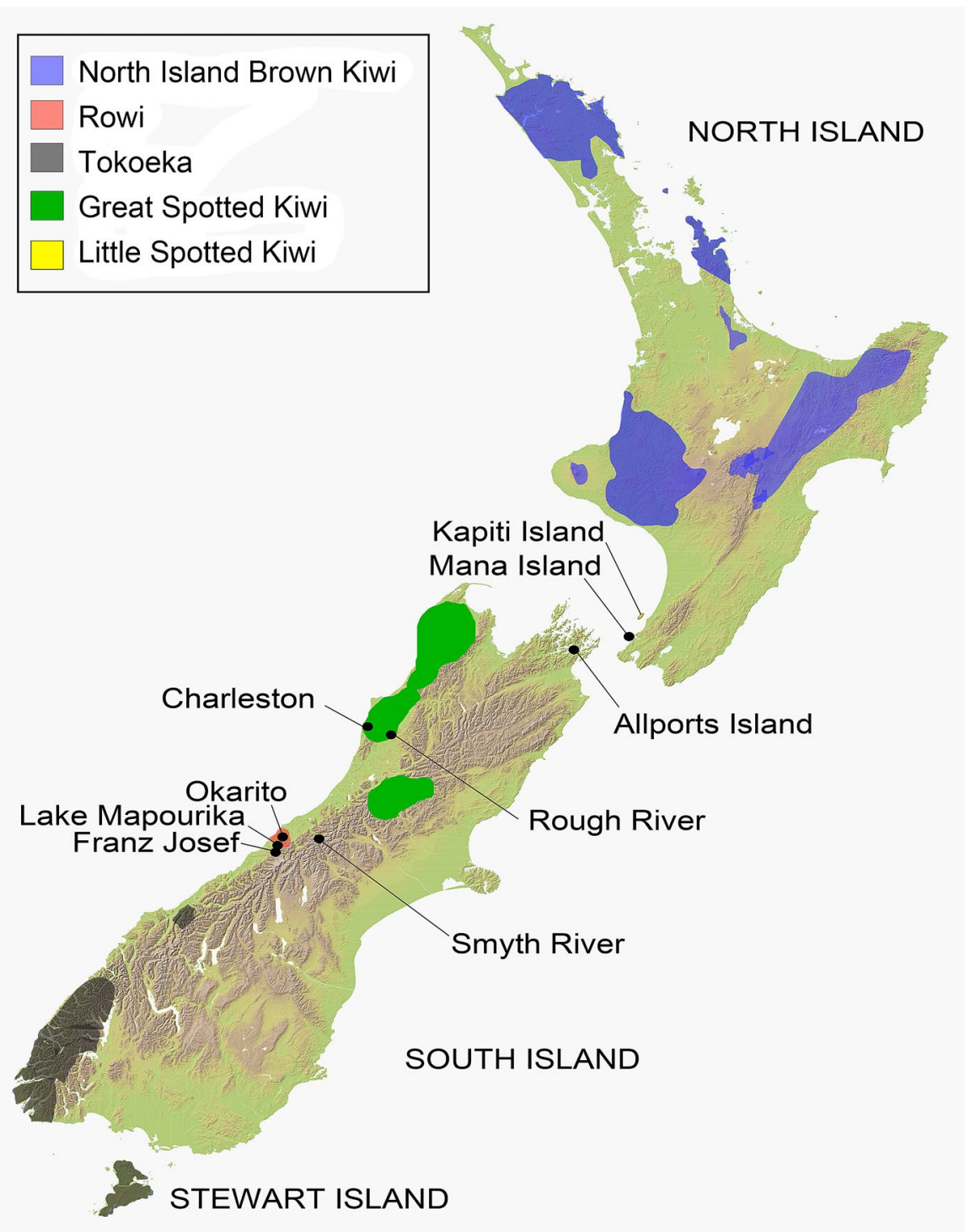

Fig. 1 The present-day distributions of the five kiwi species. The largest and oldest Little Spotted Kiwi population is on Kapiti Island but a number of other translocated populations have been established via translocation (not shown). Locations mentioned in the text, including where kiwi hybrids have been found, are mapped

or retain genetically depauperate purebred populations (Ramstad et al. 2021; Undin et al. 2021)?

In this study we examine hybridisation between Little Spotted Kiwi and Rowi. Our objectives are to (1) determine the extent of past and present introgression between wild populations of Rowi and Little Spotted Kiwi at Okarito; and (2) investigate whether the syntype specimens of $A$. haastii Potts, 1872 are hybrids and discuss the taxonomic implications of our findings.

\section{Methods}

\section{Sampling}

We refer to individual sampled kiwi by their names or museum registration numbers (Table 1). AllportsM is a male kiwi first caught near Franz Josef township in 1992 and moved to Mana Island in 1992 (Hugh Robertson, pers. comm.; Fig. 1). He was initially thought to be a Great Spotted Kiwi when first discovered (Jim Jolly, unpubl. report) based on the presence of barred feathers, which are characteristic of spotted but not brown kiwi. However, subsequent allozyme analyses 
Table 1 Details about individual kiwi (Apteryx sp.) analysed in this study

\begin{tabular}{|c|c|c|c|}
\hline Name/museum registration number & Past species identification & $\begin{array}{l}\text { Species identification } \\
\text { (this study) }\end{array}$ & Collection location \\
\hline AllportsM & Rowi $\times$ LSK (F1) & Rowi x LSK (F1) & Allports Island (ex. Franz Josef) \\
\hline Jess & Rowi $\times$ LSK (F1) & Rowi $\times$ LSK (F1) & Allports Island (ex. Okarito) \\
\hline AllportsChick & Rowi x LSK (F2) & Rowi x LSK (F2) & Allports Island (offspring of Jess and AllportsM) \\
\hline BC0102_3 & $($ Rowi $\times$ LSK) $\times$ Rowi $(B C 1)$ & Rowi $\times$ LSK $(B C 3+)$ & Okarito \\
\hline NMNZ OR.30701 & Rowi $\times$ LSK or Rowi $\times$ GSK & $\begin{array}{l}\text { Later generation hybrid } \\
\text { between Rowi } \times \text { GSK or } \\
\text { Rowi } \times \text { LSK }\end{array}$ & Okarito (1945-1947) \\
\hline $\begin{array}{l}\text { CM AV2828 } \\
\text { (A. haasti syntype) }\end{array}$ & GSK & Rowi $\times$ LSK & $\begin{array}{l}\text { Between Lake Mapourika and the Southern } \\
\text { Alps (1870-1871) }\end{array}$ \\
\hline $\begin{array}{l}\text { CM AV2829 } \\
\text { (A. haasti syntype) }\end{array}$ & GSK & Rowi $\times$ GSK or Rowi $\times$ LSK & Upper reaches of the Okarito River (1870-1871) \\
\hline A_maxima neotype (NMNZ OR.22663) & GSK & GSK & Near Charleston \\
\hline
\end{tabular}

Past species identification is based on morphology and/or published genetic results. Species identification in this study is based on all available information

LSK Little Spotted Kiwi, GSK Great Spotted Kiwi, NMNZ Museum of New Zealand Te Papa Tongarewa

and mtDNA sequencing suggested that he was a hybrid between a female Rowi and a male Little Spotted Kiwi (Herbert and Daugherty 2002). In 2006, AllportsM was moved to Allports Island in Queen Charlotte Sound (Miskelly 2010; Fig. 1). Jess is a female kiwi found at Okarito in 2005 and subsequently also moved to Allports Island. Based on morphology (barred feathers), Jess was considered to be a hybrid between a Rowi and Little Spotted Kiwi. AllportsM and Jess produced two known chicks, of which one, AllportsChick, was sampled. An Okarito bird, BC0102_3, was thought to be the offspring of Jess and a Rowi male, produced before Jess was moved to Allports Island. If confirmed, this would make BC0102_3 a first generation Rowi backcross. Feathers were plucked for DNA analyses from AllportsM, Jess, AllportsChick and BC0102_3.

NMNZ OR.30701 is a kiwi from Okarito whose feathers were sampled on several occasions in the wild between 1945 and 1947, and sent to Robert Falla who was Director of the Canterbury Museum at the time. Labels by Falla include information such as "Okarito Kiwi Cross" and "Feathers of the Okarito kiwi (australis? $\times$ haasti?)". We analyzed the base of one of these feathers.

Three kiwi museum skins were sampled by removing a sliver of approximately $3 \mathrm{~mm}^{2}$ of footpad tissue from the underside of a toe with a clean razor blade. These were the two syntype specimens of $A$. haastii (CM AV2828 and CM AV2829), both of which are thought to be females based on their long bills (Scofield 2004) and the neotype specimen of A. maxima Sclater and Hochstetter, 1861, which was collected near Charleston in 1981 and determined to be female by dissection (NMNZ OR.22663; Palma et al. 2003). Apteryx maxima is currently considered to be an invalid name (nomen oblitum) for Great Spotted Kiwi (Palma et al. 2003).

\section{DNA extraction}

Feather samples from living kiwi were processed in a laboratory where only modern samples and PCR products are processed. DNA from historic samples was handled in an ancient DNA laboratory, physically isolated from areas where modern DNA and PCR products were handled. Potential contamination was monitored by the use of negative extraction and PCR controls.

Genomic DNA was extracted from the feathers and footpad samples with a Qiagen DNEasy ${ }^{\circledR}$ Blood and Tissue extraction kit. The manufacturer's instructions were followed, except that for the historic samples the final elution used $50 \mu \mathrm{l}$ of Buffer $\mathrm{AE}$ and was spun through the column twice (i.e. the first elution was placed back on the column and spun through a second time).

\section{Mitochondrial DNA sequencing and analyses}

Variable fragments of two mitochondrial genes were targeted. A 200-base pair (bp) fragment of domain 1 of the control region was amplified using the kcf and kcr primers of Shepherd and Lambert (2008). A 471 bp fragment of the cytochrome $b$ was amplified in two overlapping fragments and one non-contiguous fragment using the primers of Shepherd et al. (2012).

PCRs were performed in $12 \mu \mathrm{L}$ volumes with $1 \times$ Mytaq mix (Bioline, Australia), 5 pmol of each primer and 2 $\mathrm{mg} / \mathrm{mL}$ bovine serum albumin (BSA). PCR thermocycling conditions were an initial denaturation of $95{ }^{\circ} \mathrm{C}$ for $1 \mathrm{~min}$ followed by 45 cycles of $95{ }^{\circ} \mathrm{C}$ for $20 \mathrm{~s}, 50{ }^{\circ} \mathrm{C}$ for $20 \mathrm{~s}$, and $72{ }^{\circ} \mathrm{C}$ for $20 \mathrm{~s}$ and a final extension at $72{ }^{\circ} \mathrm{C}$ for $5 \mathrm{~min}$. PCR products were visualised by agarose gel 
electrophoresis then purified by digestion with $0.5 \mathrm{U}$ shrimp alkaline phosphatase (SAP, New England Biolabs, MA, USA) and $2.5 \mathrm{U}$ exonuclease I (ExoI, New England Biolabs, MA, USA) at $37^{\circ} \mathrm{C}$ for $15 \mathrm{~min}$, followed by inactivation of the enzymes at $80{ }^{\circ} \mathrm{C}$ for $15 \mathrm{~min}$. PCR fragments were sequenced in both directions with the $\mathrm{ABI}$ Prism Big Dye Terminator cycle sequencing kit version 3.1 on an ABI 3730 DNA sequencer (Massey Genome Service, Massey University, Palmerston North, New Zealand).

Sequence files were edited with Sequencher version 5.2 (Gene Codes Corp., Ann Arbor, MI, USA). Sequences contained no indels and were aligned by eye to 56 published mitochondrial control region and cytochrome $b$ sequences (Additional file 1: Table S2) representing the genetic diversity discovered to date in modern and ancient kiwi (Baker et al. 1995; Burbidge et al. 2003; Shepherd and Lambert 2008; Shepherd et al. 2012; Weir et al. 2016).

Maximum likelihood (ML) analyses were performed with the PhyML v3.0 web server (http://www.atgc-montp ellier.fr/phyml/; Guindon et al. 2010), with the best-fit model of sequence evolution determined with Smart Model Selection (HKY85) and the Akaike information criterion (Lefort et al. 2017). Heuristic searches were performed with 10 random addition sequence replicates and SPR branch-swapping. Branch support was assessed with 1000 bootstrap (BS) pseudoreplicates.

MrBayes v3.2.1 (Ronquist et al. 2012) was used to perform Bayesian analyses (BA). Two concurrent analyses were run, each with four Markov chains of ten million generations and sampling every 1000 generations, $\mathrm{nst}=6$, rates $=$ invgamma, the default priors, and the substitution model parameters unlinked across the two loci. The first $20 \%$ of samples were discarded as "burn-in", after this point the standard deviation of split frequencies was below 0.01 and convergence was confirmed by checking plots of $-\ln L$ across generations and ESS for each parameter ( $>200$ for all cases) with Tracer v.1.71 (Rambaut et al. 2018).

\section{Microsatellite genotyping and analyses of modern samples} The three suspected hybrid kiwi on Allports Island, plus BC0102_3 from Okarito, were genotyped at 36 published microsatellite loci (Apt35, Apt59 and Apt68 from Shepherd and Lambert 2006; KMS1, KMS18, KMS37 and KMS74B from Jensen et al. 2008; Aptowe1, Aptowe2, Aptowe3, Aptowe7, Aptowe8, Aptowe23, Aptowe24, Aptowe28, Aptowe29, Aptowe31, Aptowe34, Aptowe35 and Aptowe39 from Ramstad et al. 2010; Rowi1, Rowi2, Rowi6, Rowi10, Rowi14, Rowi16, Rowi17, Rowi18, Rowi22, Rowi23, Rowi28, Rowi33, Rowi46, Rowi63, Rowi69 and Rowi77 from Jia et al. (2021).
PCR amplification and genotyping were performed as described in supplementary file 2 of Jia et al. (2021).

In order to examine potential introgression between Little Spotted Kiwi and Rowi at Okarito, data for 36 microsatellite loci from 300 Rowi, 10 Little Spotted Kiwi (Ramstad et al. 2013, 2021) and the recent putative hybrids (AllportsM, Jess and AllportsChick) were included in our analyses (data deposited in Dryad: https://doi.org/10.5061/dryad.ghx3ffbnz). The Rowi sampling represented $70 \%$ of individuals of the entire species at the time that these samples were collected. Of the 36 loci included in this paper, 20 were previously published and vetted for null alleles and reliable amplification (Shepherd and Lambert 2006; Jensen et al. 2008; Ramstad et al. 2010), while 16 were recently developed in Rowi (Jia et al. 2021) and are genotyped broadly for the first time here. For the 16 Rowi loci included in this analysis, evidence of null alleles was assessed in MICROCHECKER (v2.2.3; van Oosterhout et al. 2004) and gametic disequilibrium (GD) was assessed by calculating the standardized composite linkage disequilibrium coefficient $\left(D^{\prime}\right)$ in GDA (v1.1; Lewis and Zaykin 1999) without assuming Hardy Weinberg proportions (Weir 1996; Schaid 2004).

We used HYBRIDLAB (Nielsen et al. 2006) to simulate 50 first generation Rowi backcrosses (BC1) and 50 second generation Rowi backcrosses (BC2) for these 36 microsatellite loci. $\mathrm{BC} 1$ individuals represent genotypes that would result from a cross between a first generation Little Spotted Kiwi $\times$ Rowi hybrid and a pure Rowi, while $\mathrm{BC} 2$ genotypes are expected from a cross between a $\mathrm{BC} 1$ hybrid and a pure Rowi. $\mathrm{BC} 1$ individuals were simulated from crosses between the adults on Allports (AllportsM and Jess, which are first generation Little Spotted Kiwi $\times$ Rowi hybrids) and the 300 genotyped Okarito Rowi (parents randomly selected). $\mathrm{BC} 2$ genotypes were simulated as resulting from crosses between the $50 \mathrm{sim}$ ulated $\mathrm{BC} 1$ birds and the 300 genotyped Okarito Rowi. Evidence of introgression was assessed with principal components analysis (PCA) and Bayesian admixture analysis of the resulting simulated microsatellite genotypes. PCA was conducted for individuals in GENALEX (v 6.4; Peakall and Smouse 2006) with the algorithm of Orlóci (1975) and using the standardized covariance matrix calculated from a genetic distance matrix described in Smouse and Peakall (1999). The proportion of admixture within individual birds was assessed in STRUCTURE v2.3.4 (Pritchard et al. 2000; Falush et al. 2007) assuming an admixture model and independent allele frequencies between Little Spotted Kiwi and Rowi, and by constraining individuals to fit into one of two genetic groups $(K=2)$. The analysis was run with a burnin of 10,000 generations followed by 100,000 Markov Chain Monte Carlo (MCMC) iterations. A hybrid index 
score $(q)$ results from this analysis, which is the relative probability that the multilocus genotype of an individual arose by random mating within each of the parental taxa $(0=$ Rowi and $1=$ Little Spotted Kiwi; Allendorf et al. 2001).

Microsatellite genotyping and analyses of historic samples A subset of 13 microsatellite loci (Aptowe1, Aptowe2, Aptowe3, Aptowe7, Aptowe8, Aptowe23, Aptowe24, Aptowe28, Aptowe31, Aptowe34, Aptowe35, Aptowe39 and Apt59) were genotyped in the historic samples (A. maxima neotype, OR.30701, CM AV2828 and CM AV2829). These loci were selected because they had been previously shown to amplify in all kiwi species and had also been broadly surveyed in Little Spotted Kiwi. For the analyses of this reduced dataset, the Allports male and female were also included, as well as published microsatellite genotypes from 6 samples each of North Island Brown Kiwi, Tokoeka and Great Spotted Kiwi (Ramstad et al. 2010), 10 randomly selected samples of Rowi (Ramstad et al. 2021) and 13 samples of Little Spotted Kiwi (7 from the extant population on Kapiti Island and 6 historic samples from the South Island; Ramstad et al. 2021). PCA was conducted for individuals in GENALEX, as described above.

STRUCTURE v2.3.4 was used to examine genetic structuring within the reduced dataset, without a priori inferences. The number of genetic clusters $(K)$ was set between one to seven, with ten permutations for each. The admixture model with independent allele frequencies was used with a burn-in of 100,000 generations followed by 500,000 MCMC iterations. The optimal number of genetic clusters $(K)$ was determined by calculating the $\Delta K$ statistic (Evanno et al. 2005) in STRUCTURE HARVESTER web v.0.6.94 (Earl and vonHoldt 2012). All clustering results that had a biologically interpretable pattern were also examined, following Meirmans (2015). CLUMPP v.1.1.2 (Jakobsson and Rosenberg 2007) was used to average the 10 permutations and the results graphed with STRUCTURE PLOT v.2.0 (Ramasamy et al. 2014).

\section{Morphology}

We collated measurements for the five kiwi species, as well as for the A. haastii and A. maxima type specimens (Palma et al. 2003; Scofield 2004). However, useful standard external measurements are difficult to obtain for kiwi (Marchant and Higgins 1990). Measurements of kiwi taken by different observers are likely to differ because kiwi have tiny wings, robust legs that are fleshy around the joints, and there is exposed flesh at the base of their beaks between the rampthotheca and feathers.
Furthermore, measurements from dried kiwi specimens are difficult to compare to those from living birds.

\section{Results \\ DNA sequence analysis}

The alignment of the concatenated mitochondrial control region and cytochrome $b$ DNA sequence fragments was 661 base pairs (bp) in length. Only the control region fragment (190 bp) could be amplified from the A. haastii syntype specimens (CM AV2828 and CM AV2829) and translation of these ancient DNA sequences into protein showed that they did not contain any stop codons. Cytochrome $b$ was coded as missing data for these two specimens in the phylogenetic analyses.

The maximum likelihood (ML) and Bayesian phylogenies had similar topologies to each other and to published mtDNA phylogenies (Burbidge et al. 2003; Shepherd et al. 2012; Weir et al. 2016), with no strongly supported conflicting nodes. The Bayesian phylogeny, with support values from both analyses, is shown in Fig. 2. The sequences of the putative hybrids clustered in different parts of the phylogeny. CM AV2829, OR.30701, Jess and AllportsM grouped with Rowi in the phylogeny (0.96 posterior probability (PP)), specifically in a clade with Rowi from Okarito, which is the only extant population of this species (97\% ML bootstrap support (BS)). The sequences from CM AV2829, Jess and AllportsM were identical to each other and to published Rowi sequences from Okarito. OR.30701 differed from the most closelyrelated Rowi sequence by one mutation (a transition) in the control region.

CM AV2828 had a sequence identical to that found in Little Spotted Kiwi from the South Island and Kapiti Island, and grouped with spotted kiwi with high support (1.00 PP and $100 \%$ ML BS) in the phylogeny. The A. maxima neotype specimen grouped with Great Spotted Kiwi in the mtDNA phylogeny (1.00 PP/89\% ML BS), and was identical to published Great Spotted Kiwi sequences.

\section{Microsatellite analyses of modern sample (36 microsatellite dataset)}

We found no evidence of null alleles and only weak gametic disequilibrium among loci $\left(D^{\prime}<0.2\right)$. Thus, no loci were excluded from further analysis. With the 36 microsatellite locus dataset, both the PCA and STRU CTURE analyses indicated that Rowi and Little Spotted Kiwi are genetically distinct (Figs. 3, 4). In the PCA, Little Spotted Kiwi, first generation hybrids (F1s; AllportsM and Jess), BC1s and Rowi could all be clearly distinguished from one another on the first principal component, which explains $13 \%$ of the total variation in 


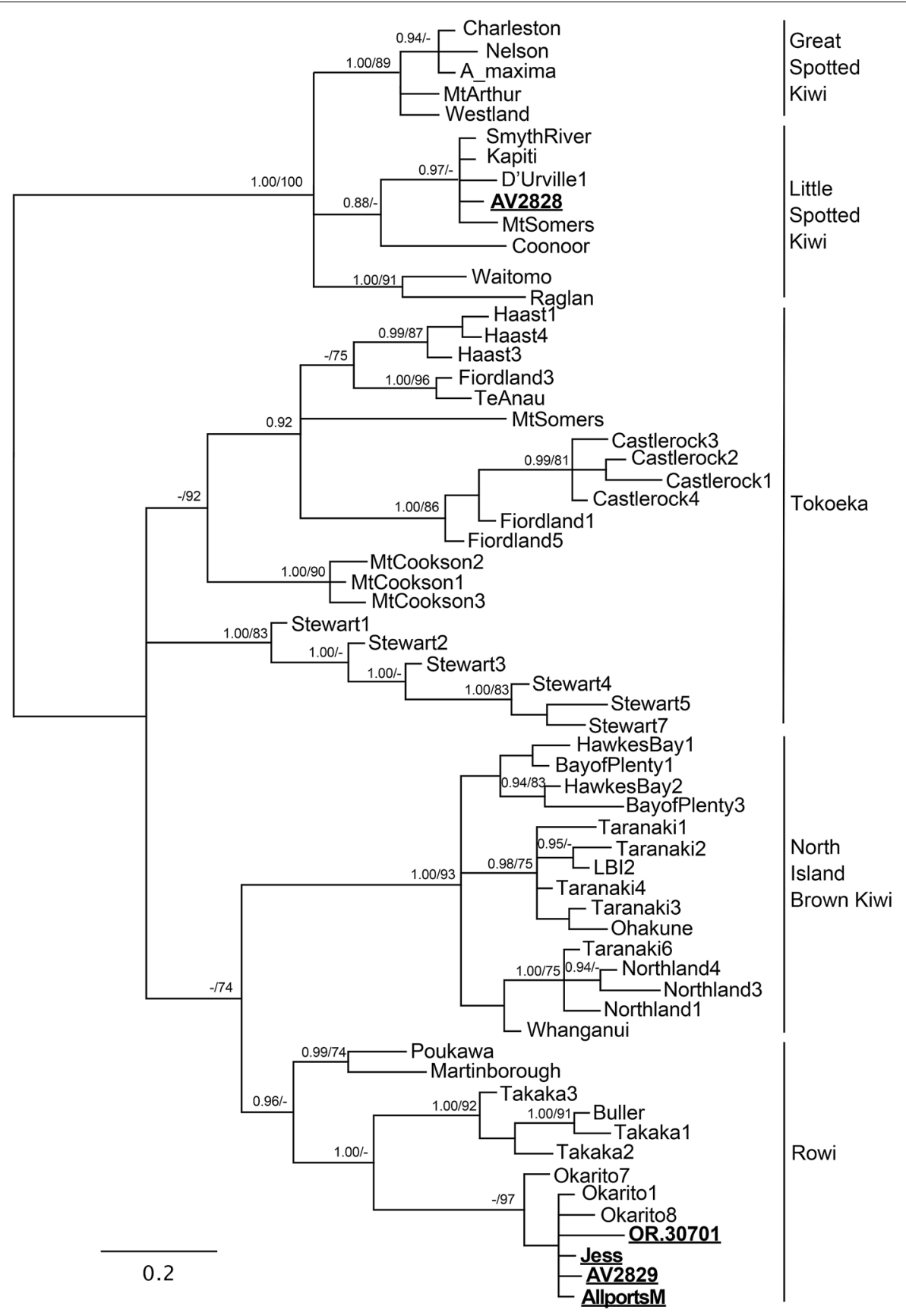

Fig. 2 Midpoint rooted Bayesian phylogeny of the concatenated control region and cytochrome $b$ DNA sequences. Numbers above the branches represent Bayesian posterior probabilities (PP) and maximum likelihood bootstrap support values (BS), respectively. Only PP $\geq 0.90$ and BS $\geq 70 \%$ are shown. Putative hybrids are shown in bold

genotypes. However, it is difficult to distinguish between simulated first (BC1) and second generation (BC2) backcrosses and between simulated BC2s and Rowi (Fig. 3).

BC0102_3, thought to be the offspring of Jess and a Rowi male before Jess was moved from Okarito to Allports Island, did not group with the simulated $\mathrm{BC} 1 \mathrm{~s}$ and only had two of the 24 'Little Spotted Kiwi' alleles found in Jess, suggesting that Jess was not the mother and that BC0102_3 may be a third or later generation Rowi backcross $(\mathrm{BC} 3+)$. The PCA suggests that none of the other 300 Okarito birds genotyped are first generation backcrosses or more recent hybrids. 

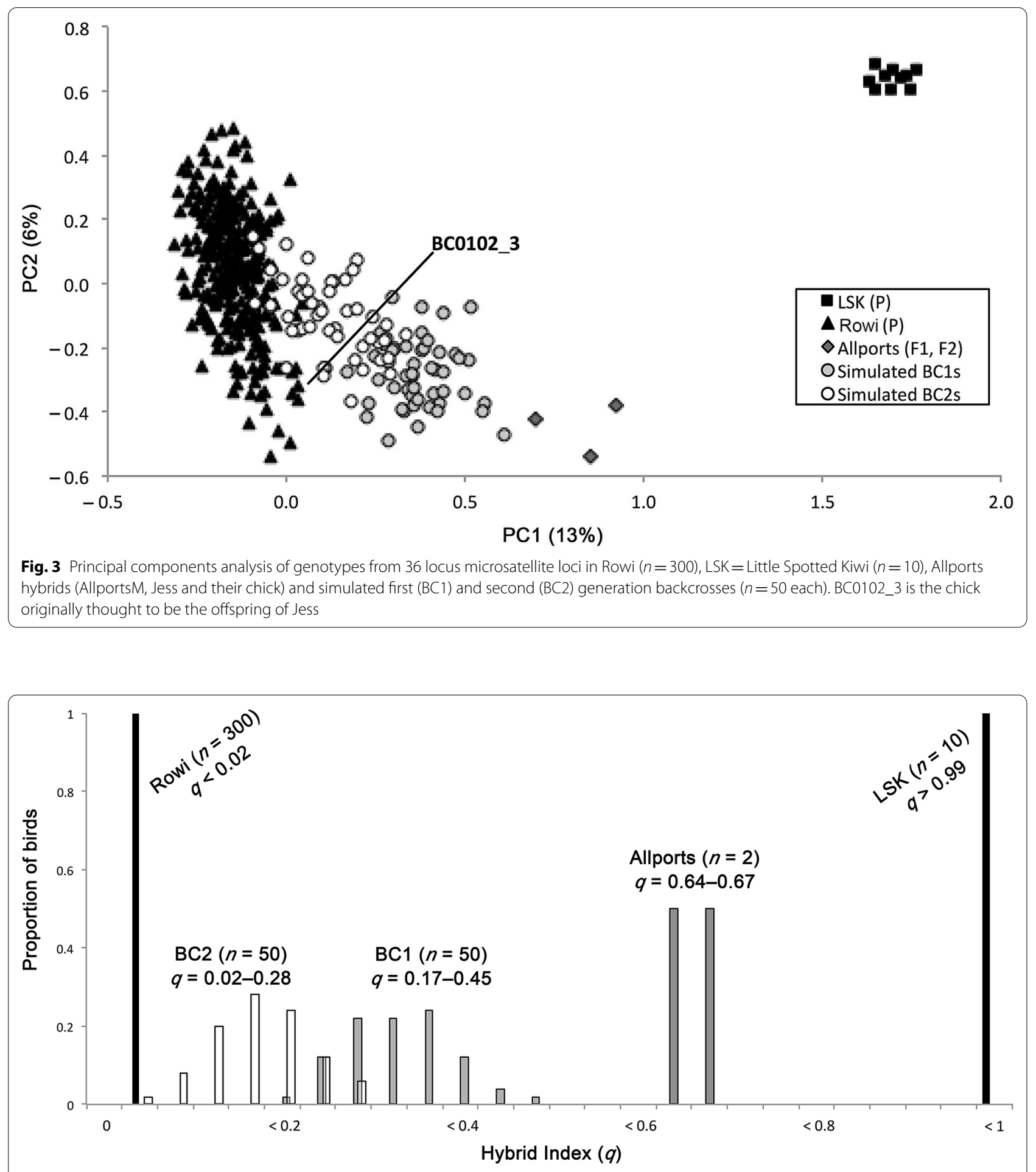

Fig. 4 Hybrid index (q; proportion of Little Spotted Kiwi (LSK) alleles) determined in STRUCTURE, for Rowi, LSK, Allports F1 hybrids, and simulated first and second backcrosses. Rowi $q$ ranges from 0.001 to 0.019 and BC0102_3 (not shown) has a $q$ of 0.020

STRUCTURE is more powerful than PCA for differentiating between Rowi and $\mathrm{BC} 2 \mathrm{~s}$. The hybrid index differentiates between all classes, except for a zone of overlap between $\mathrm{BC} 1 \mathrm{~s}$ and $\mathrm{BC} 2 \mathrm{~s}$ and a very narrow gap between Rowi (largest $q=0.0185$ ) and the simulated BC2s (smallest $q=0.0200$; Fig. 4). 
Microsatellite genotyping and analyses of historic samples (13 locus dataset)

The $A$. haastii syntypes, CM AV2828 and CM AV2829, only amplified at six and two loci, respectively, so these specimens were excluded from the PCA and STRUCTU $\mathrm{RE}$ analyses. Despite the low success rate, genotypes at several loci proved informative for the ancestry of CM AV2828. If we assume one Little Spotted Kiwi parent (the mother based on mtDNA), then five loci support CM AV2828 being a Rowi $\times$ Little Spotted Kiwi hybrid with two of these loci indicating this result exclusively (at Aptowe24 and Aptowe31 CM AV2828 has one allele found in Rowi but not in Little Spotted Kiwi, and another allele not found in Rowi but found in Little Spotted Kiwi). However, this is based on alleles detected in extant populations of Great Spotted Kiwi, North Island Brown Kiwi, Tokoeka and Rowi because no historical samples were genotyped for these species.

The two loci genotyped in CM AV2829 were less informative. One locus (Apt59) had two alleles not detected in our sampling of Great Spotted Kiwi, Rowi or Little Spotted Kiwi. The other locus (Aptowe28) was fixed for an allele not found in our sampling of Little Spotted Kiwi but present in Great Spotted Kiwi and Rowi. The Rowi mtDNA sequence and barred feathers of this specimen indicates that it has hybrid ancestry between Rowi and a spotted kiwi but it is difficult to determine its parentage further based solely on this data.

The A. maxima neotype amplified at 12 of the 13 loci, and OR.30701 amplified at all 13 loci. Principal components 1 and 2 accounted for $35 \%$ of the total variation in the PCA of the 13 locus dataset (Fig. 5). All of the kiwi species are distinguished in the PCA, although Tokoeka and North Island Brown Kiwi are very close to each other (Fig. 5). As in the expanded dataset, both Jess and AllportsM fall between Little Spotted Kiwi and Rowi, indicating that F1 Rowi $\times$ Little Spotted Kiwi hybrids can be distinguished, even with this reduced microsatellite dataset. The neotype specimen of $A$. maxima clusters within the Great Spotted Kiwi diversity. OR.30701 falls between Rowi and Tokoeka/North Island Brown Kiwi in the PCA. Given the lack of sympatry between Rowi and North Island Brown Kiwi or Tokoeka, the PCA indicates that OR.30701 is most likely to be a later generation hybrid between a Rowi $\times$ spotted kiwi.

For the STRUCTURE analyses of the 13 locus dataset, $\Delta K$ indicated that the optimal number of genetic clusters $(K)$ was 4 (Fig. 6). At $K=4$, most individuals were assigned with high probability to a single cluster. North Island Brown Kiwi and Tokoeka were assigned to a single cluster, and Rowi, Great Spotted Kiwi and Little Spotted Kiwi each formed separate clusters. OR.30701 was assigned to the Rowi cluster. All the alleles genotyped in this specimen were detected in Rowi but 9 alleles at 8 loci were also found in Great Spotted Kiwi, 4 alleles at 4 loci were also found in Little Spotted Kiwi, and alleles at 11 loci were also found in North Island Brown Kiwi and/or Tokoeka, potentially explaining the position of this individual in the PCA. The A. maxima neotype clustered with Great Spotted Kiwi. At 2 loci, this specimen

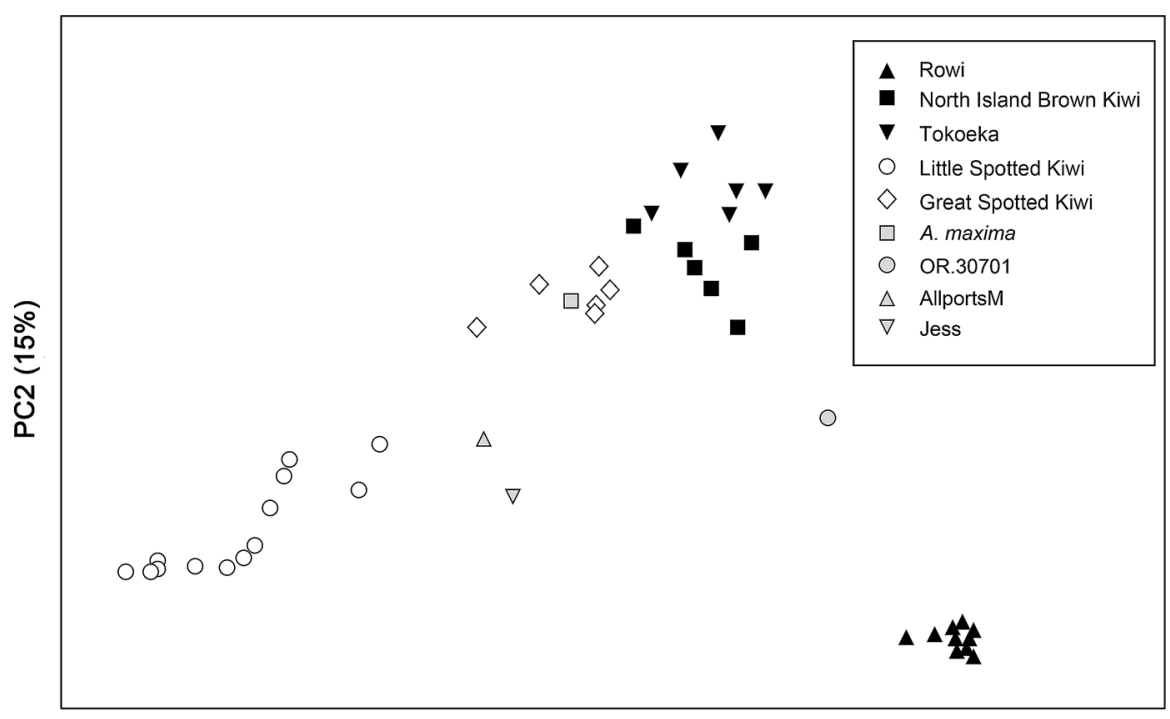

PC1 $(21 \%)$

Fig. 5 Principal components analysis of genotypes at 13 microsatellite loci in North Island Brown Kiwi $(n=6)$, Tokoeka $(n=6)$, Great Spotted Kiwi $(n=6)$, Rowi $(n=10)$, Little Spotted Kiwi $(n=13)$, the A. maxima neotype and putative hybrid kiwi 


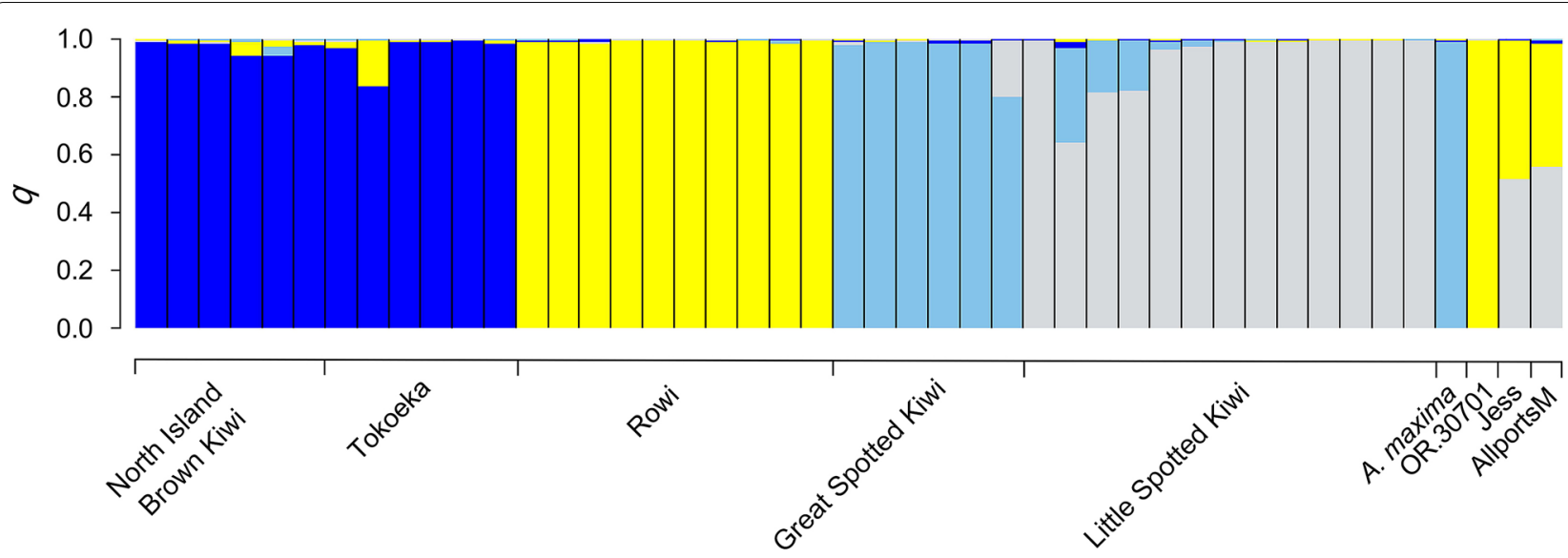

Fig. 6 STRUCTURE plot showing the assignment of individual kiwi to four clusters $(K=4)$ based on 13 microsatellite loci. Each vertical bar represents one individual, and different colors within each bar indicate genetic admixture

was homozygous for an allele fixed in Great Spotted Kiwi (Aptowe3, Aptowe7), one of which was not found in our sampling of any other kiwi species. Another 4 alleles at 4 loci in the A. maxima neotype have not been found in any other kiwi species other than Great Spotted Kiwi. Jess and AllportsM were assigned equally to the Rowi and Little Spotted Kiwi clusters. When $K$ was set at $>4$, additional clusters were partitioned across multiple samples so that many individuals were assigned to multiple clusters.

\section{Morphology}

There is much overlap in size between kiwi species (Additional file 1: Table S1). The bill measurements of the two A. haastii syntype specimens (CM AV2828 and CM AV2829) are within the recorded range of measurements for this character for female Great Spotted Kiwi. However, the tarsometatarsus length of both syntype specimens was much smaller than recorded for this species, with only male $A$. owenii having similarly short tarsometatarsi. The tarsometatarsus and bill measurements of the $A$. maxima neotype specimen are within the range recorded for female great spotted kiwi.

\section{Discussion}

\section{Hybridisation between Rowi and Little Spotted Kiwi}

Combined, our morphological, mtDNA and microsatellite analyses suggest that hybridisation between Rowi and Little Spotted Kiwi, two species that may have diverged up to 13 Mya, has been occurring in the vicinity of Okarito for at least the last 150 years, with the most recent hybrid, Jess, found in 2005. The Allports Island birds AllportsM and Jess are F1 Rowi $\times$ Little Spotted Kiwi hybrids and each has a Rowi as their mother. It is even possible that they share the same parents because their
mtDNA sequences are identical. These recent hybrids provide support for the survival of pure-bred Little Spotted Kiwi into the 1950s (or later) on the west coast of the South Island (McLennan and McCann 1990; Shepherd et al. 2012). The timing of the extinction of Little Spotted Kiwi in the South Island was poorly documented and has been the subject of considerable debate (Shepherd et al. 2012; Ramstad et al. 2021).

Not surprisingly, the sampled chick on Allports Island (AllportsChick) is confirmed as the offspring of AllportsM and Jess, the only other kiwi on the island, indicating that F1 Rowi $\times$ Little Spotted Kiwi hybrids are able to successfully reproduce. Although our analyses show that BC0102_3 is not the offspring of Jess, they do suggest that this bird may have a more distant hybrid origin (a third or later generation Rowi backcross).

Whether OR.30701, which is only preserved as feathers collected in the 1940s, has a hybrid origin is unclear from its genetic make-up alone. OR.30701 has a Rowi mtDNA genome, all of its microsatellite alleles are also found in Rowi and it grouped strongly with Rowi in the STRU CTURE analysis. However, its barred feathers indicate that it is a likely hybrid. The unique position of OR.30701 in the PCA in relation to the reference Rowi samples may also be a result of hybridisation in its ancestry. It is likely to be a later generation backcross with a Rowi, given its genetic affinity to Rowi in our analyses.

\section{Hybridisation in $A$. haastii syntypes}

The syntype specimens of $A$. haastii (CM AV2828 and CM AV2829), which were collected inland from Okarito in 1870-1871, are apparently also hybrids. Their mtDNA genomes are from what we assume are Little Spotted Kiwi (CM AV2828) and Rowi (CM AV2829). We did not sequence the primary type specimens of either 
Little Spotted Kiwi or Rowi. The holotype of $A$. owenii Gould, 1847 is missing or unidentifiable (J.A. Bartle pers. comm.), so it could not be sampled, and the holotype of A. rowi Tennyson et al. 2003, was found dead in 2002 in Okarito, so is presumed to cluster within the modern genetic range of this species. The microsatellite genotypes and morphology of the $A$. haastii syntype specimens are also inconsistent with them being pure-bred Great Spotted Kiwi. Therefore, A. haastii is not the correct name of the taxon now generally called the 'Great Spotted Kiwi'. Potts' (1872) description of $A$. haastii is based on specimens that are hybrids, with parentage from two different species. For the taxonomic implications of this conclusion see the "Resurrection of Apteryx maxima Sclater and Hochstetter, 1861" section below.

\section{Conservation and taxonomic implications of hybridisation in kiwi}

We suggest that the decline of kiwi in the South Island contributed to the level of hybridisation that we document here. Hybridisation tends to be more common in areas where one species is rare, resulting in restricted mate choice (Hubbs 1955; Randler 2002). It has been suggested that in such situations it tends to be the females of the rarer species that choose heterospecific mates (Wirtz 1999). We found evidence that both sexes of Little Spotted Kiwi were parents of hybrid offspring (reciprocal hybridisation; Wirtz 1999), although Rowi was the maternal parent for most of the hybrids we examined. Our results indicate that hybridisation in kiwi is not limited by body size differences. Wirtz (1999) reports that the female of the smaller species tends to mate with males of the larger species but Randler (2002) found no evidence for this hypothesis in a review of bird hybridisation. We found more kiwi hybrids with Rowi, which are larger than Little Spotted Kiwi, as the maternal parent (Additional file 1: Table S1). However, kiwi exhibit reverse sexual dimorphism (with females larger than males) and therefore females are used to selecting smaller mates.

Despite our finding of recurrent hybridisation between Rowi and Little Spotted Kiwi around Okarito over the last 150 years, our microsatellite data, combined with our hybrid data simulations, suggest that there are no known F1 Little Spotted Kiwi $\times$ Rowi hybrids, or first or second Rowi backcross hybrids, currently within the Rowi population at Okarito. Therefore, the genetic integrity of the last remaining Rowi population at Okarito has not been compromised by significant recent introgression of Little Spotted Kiwi alleles.

There are no known hybrids between Little Spotted Kiwi and Great Spotted Kiwi, which previously had overlapping distributions. Hybridisation between them may be possible given that Tokoeka, which can reach a similar size to Great Spotted Kiwi, and Little Spotted Kiwi, can hybridise (Jason Weir, pers. comm), despite Tokoeka and Little Spotted Kiwi being more distantly related. If hybridisation does occur between Little Spotted Kiwi and Great Spotted Kiwi then hybrids would be difficult to distinguish morphologically because the two parent species are very similar apart from body size. The distributions of Little Spotted Kiwi and Great Spotted Kiwi no longer overlap but several historical specimens may represent hybrids between them. These specimens host unexpected feather lice, suggesting that they could have hybrid ancestry because the phylogenetic relationships of lice often parallel those of their hosts (Pilgrim and Palma 1982). NMNZ OR.1174, found in 1952 at Rough River in Westland, and NMNZ OR.23043, found at Smyth River in South Westland in 1978 both have Little Spotted Kiwi mtDNA (Shepherd et al. 2012) but a feather louse species (Rallicola (Aptericola) gracilentus Clay, 1953) that is otherwise only associated with Great Spotted Kiwi (Palma 2017). Alternatively, the $R$. gracilentus on these specimens may be 'stragglers' (Pilgrim and Palma 1982), which have been transferred via interactions apart from mating, such as fighting or the use of the same nest or roost sites.

\section{Resurrection of Apteryx maxima Sclater and Hochstetter, 1861}

Our genetic analyses demonstrate that Potts' (1872) description of $A$. haastii was based on two hybrid individuals and therefore this name does not represent what is commonly known today as the 'Great Spotted Kiwi'. The next available name for the 'Great Spotted Kiwi' is A. maxima Sclater and Hochstetter, 1861, which was declared a nomen oblitum by Palma et al. (2003) under Article 23.9 (the Reversal of precedence) of the International Code of Zoological Nomenclature (Ride et al. 1999) in order to conserve nomenclatural stability. Our genetic data from the type specimen of $A$. maxima (NMNZ OR.22663) confirms that it is (1) not a hybrid, and (2) representative of the species today known as the 'Great Spotted Kiwi'. Therefore, we resurrect the name Apteryx maxima for the 'Great Spotted Kiwi' under Article 23.3.5.

\section{Conclusions}

Our morphological and genetic analyses of kiwi revealed that hybridisation between Rowi and Little Spotted Kiwi has likely been occurring at Okarito for the last 150 years. This is surprising given estimates of the time of divergence between the two species range from 4 to 13 million years ago. Despite this hybridisation we found no evidence of F1, first or second generation Rowi backcross hybrids within the extant Rowi population. We also 
demonstrate that the syntype specimens of $A$. haastii are apparently also hybrids so we resurrect the name $A$. maxima for the 'Great Spotted Kiwi.'

\section{Supplementary Information}

The online version contains supplementary material available at https://doi. org/10.1186/s40657-021-00257-6.

Additional file 1: Table S1. Morphological measurements of kiwi species and hybrid individuals analysed in this paper.

Additional file 2: Table S2. Kiwi specimens used for mtDNA phylogenetic analyses.

\section{Acknowledgements}

We thank Leon Huynen for performing the DNA extractions of the Great Spotted Kiwi syntypes, Paul Scofield (Canterbury Museum) for granting him permission to sample these specimens and Ricardo Palma for discussions on kiwi nomenclature.

\section{Authors' contributions}

$K R, A T, R C$ and $H R$ conceived the study; KR, HR, RC and LS collected the data; LS and KR analysed the data and drafted the manuscript; AT, RC and HR commented on the manuscript. All authors read and approved the final manuscript.

\section{Funding}

KR was supported by the Allan Wilson Centre for Molecular Ecology and Evolution, the Bank of New Zealand Save the Kiwi Trust, and the New Zealand Department of Conservation. LS was funded by a Rutherford Discovery Fellowship from the Royal Society of New Zealand (contract number RDF-MNZ1201).

\section{Availability of data and materials}

DNA sequences have been deposited in the GenBank repository and accession numbers are given in Additional file 2: Table $\mathbf{S 2}$

\section{Declarations}

Ethics approval and consent to participate

Handling and sampling of kiwi was carried out according to the Kiwi Best Practice Manual (Colbourne et al. 2017) under New Zealand Department of Conservation authority, with approval of the Victoria University of Wellington Animal Ethics Committee, and with quidance from the indigenous Māori communities of the sampling areas.

\section{Consent for publication}

Not applicable.

\section{Competing interests}

Not applicable.

\section{Author details}

${ }^{1}$ Museum of New Zealand Te Papa Tongarewa, Wellington 6011, New Zealand. ${ }^{2}$ Biodiversity Group Department of Conservation, PO Box 10420, Wellington 6011 , New Zealand. ${ }^{3}$ Department of Biology and Geology, University of South Carolina Aiken, 471 University Parkway, Aiken, SC 29801, USA.

Received: 1 October 2020 Accepted: 30 April 2021

Published online: 21 May 2021

\section{References}

Allendorf FW, Leary RF, Spruell P, Wenburg JK. The problems with hybrids: setting conservation guidelines. Trends Ecol Evol. 2001;16:613-22.
Allendorf FW, Luikart G, Aitken SN. Conservation and the genetics of populations. 2nd ed. Maldon: Wiley-Blackwell Publishing; 2012.

Anderson E, Stebbins GL Jr. Hybridization as an evolutionary stimulus. Evolution. 1954;8:378-88.

Baker AJ, Daugherty CH, Colbourne R, McLennan JL. Flightless brown kiwis of New Zealand possess extremely subdivided population structure and cryptic species like small mammals. Proc Natl Acad Sci USA. 1995;92:8254-8.

Barlow S. Captive management plan for kiwi. Final 2018-2023. In: Zoo and Aquarium Association. 2018. https://www.kiwisforkiwi.org/wp-content/ uploads/2018/10/2018_FINAL_ZAA_DOC_kiwi_cmp.pdf. Accessed 10 Sept 2020.

BirdLife International. Okarito Kiwi Apteryx rowi. The IUCN Red List of Threatened Species 2017: e.T22732871A119169794. 2017. https://doi.org/10. 2305/IUCN.UK.2017-3.RLTS.T22732871A119169794.en. Accessed 25 May 2020

Burbidge ML, Colbourne RM, Robertson HA, Baker AJ. Molecular and other biological evidence supports the recognition of at least three species of brown kiwi. Conserv Genet. 2003;4:167-77.

Colbourne R. Kiwi (Apteryx spp.) on offshore New Zealand islands: populations, translocations and identification of potential release sites. In: DOC Research and Development Series 208. 2005. https://www.doc.govt.nz/ globalassets/documents/science-and-technical/drds208.pdf.

Colbourne R, Bean E, Coad N, Fuchs R, Graham I, Robertson H, et al. Kiwi best practice manual. Wellington: Department of Conservation; 2017. https:// www.doc.govt.nz/globalassets/documents/science-and-technical/sap26 2entire.pdf.

Earl DA, vonHoldt BM. STRUCTURE HARVESTER: a website and program for visualizing STRUCTURE output and implementing the Evanno method. Conserv Genet Res. 2012;4:359-61.

Evanno G, Regnaut S, Goudet J. Detecting the number of clusters of individuals using the software STRUCTURE: a simulation study. Mol Ecol. 2005; 14:2611-20.

Falush D, Stephens M, Pritchard JK. Inference of population structure using multilocus genotype data: dominant markers and null alleles. Mol Ecol Notes. 2007:7:574-8.

Germano J, Barlow S, Castro I, Colbourne R, Cox M, Gillies C, et al. Kiwi Recovery Plan 2018-2028 Mahere Whakaora Kiwi 2018-2028. In: Threatened Species Recovery Plan 64. 2018. https://www.doc.govt.nz/globalassets/ documents/science-and-technical/tsrp64entire.pdf.

Gill BJ, Bell BD, Chambers GK, Medway DG, Palma RL, Scofield RP, et al. Checklist of the birds of New Zealand, Norfolk and Macquarie Islands, and the Ross Dependency, Antarctica. 4th ed. Wellington: Ornithological Society of New Zealand \& Te Papa Press; 2010.

Grealey A, Phillips M, Miller G, Gilbert MTP, Rouillard J-M, Lambert DM, et al. Eggshell palaeogenomics: palaeognath evolutionary history revealed through ancient nuclear and mitochondrial DNA from Madagascan elephant bird (Aepyornis sp.) eggshell. Mol Phylogenet Evol. 2017:109:151-63.

Guindon S, Dufayard JF, Lefort V, Anisimova M, Hordijk W, Gascuel O. New algorithms and methods to estimate maximum-likelihood phylogenies: assessing the performance of PhyML 3.0. Syst Biol. 2010;59:307-21.

Heather BD, Robertson HA, Onley D. The field quide to the birds of New Zealand. Auckland: Penguin; 2015

Hedrick PW. Adaptive introgression in animals: examples and comparison to new mutation and standing variation as sources of adaptive variation. Mol Ecol. 2013;22:4606-18.

Herbert J, Daugherty CH. Genetic variation, systematics and management of kiwi (Apteryx spp.). In: Overmars F, editor. Some early 1990s studies in kiwi. Science and Research Internal Report 191. Wellington: Department of Conservation; 2002. pp. 11-34.

Hubbs CL. Hybridization between fish species in nature. Syst Biol. 1955:4:1-20.

Jakobsson M, Rosenberg NA. CLUMPP: a cluster matching and permutation program for dealing with label switching and multimodality in analysis of population structure. Bioinformatics. 2007;23:1801-6.

Jensen J, Nutt KJ, Seal B, Fernandes LB, Durrant B. Permanent genetic resources: isolation and characterization of microsatellite loci in the North Island brown kiwi, Apteryx mantelli. Mol Ecol Res. 2008;8:399-401.

Jia XY, Li W, Ramstad KM, Tu B, Yan J. Microsatellite records for volume 13, issue 1. Conserv Genet Resour. 2021:13(1):107-9. 
Lamichhaney S, Han F, Webster MT, Andersson L, Grant BR, Grant PR. Rapid hybrid speciation in Darwin's finches. Science. 2018;359:224-8.

Lefort V, Longueville J-E, Gascuel O. SMS: smart model selection in PhyML. Mol Biol Evol. 2017;34:2422-4.

Lewis P, Zaykin D. Genetic data analysis: software for the analysis of discrete genetic data. Computer program distributed by the authors. Storrs: University of Connecticut; 1996.

Marchant S, Higgins PJ. Handbook of Australian, New Zealand and Antarctic birds, Ratites to Ducks, vol. 1. Melbourne: Oxford University Press; 1990.

Marques DA, Meier Jl, Seehausen O. A combinatorial view on speciation and adaptive radiation. Trends Ecol Evol. 2019;34:531-44.

Masello JF, Quillfeldt P, Sandoval-Castellanos E, Alderman R, Calderón L, Cherel $Y$, et al. Additive traits lead to feeding advantage and reproductive isolation, promoting homoploid hybrid speciation. Mol Biol Evol. 2019;36:1671-85.

McLennan J, McCann T. Genetic variability, distribution and abundance of great spotted kiwi (Apteryx haastii). In: Overmars F, editor. Some early 1990s studies in kiwi. Science and Research Internal Report 191. Wellington: Department of Conservation; 2002. pp. 35-56.

McLennan JA, Potter MA, Robertson HA, Wake GC, Colbourne R, Dew L, et al. Role of predation in the decline of kiwi Apteryx spp. in New Zealand. N Z J Ecol. 1996;20:27-35.

Meirmans PG. Seven common mistakes in population genetics and how to avoid them. Mol Ecol. 2015;24:3223-31.

Miskelly C. Mana Island ecological restoration plan review. Wellington: Department of Conservation; 2010.

Nielsen EE, Bach LA, Kotlicki P. HYBRIDLAB (version 10): a program for generating simulated hybrids from population samples. Mol Ecol Notes. 2006;6:971-3.

Orlóci L. Multivariate analysis in vegetation research. 2nd ed. The Hague: DrW. Junk Publishers; 1975

Ottenburghs J, Ydenberg RC, van Hooft P, van Wieren SP, Prins HHT. The avian hybrids project: gathering the scientific literature on avian hybridization. Ibis. 2015;157:892-4.

Palma RL. Phthiraptera (Insecta): a catalogue of parasitic lice from New Zealand. Fauna of New Zealand. 2017;76:1-400.

Palma RL, Worthy TH, Tennyson AJD. Resolution of the status of the taxon Apteryx maxima. Tuhinga. 2003;14:1-9.

Peakall R, Smouse PE. GENALEX6: genetic analysis in Excel, population genetic software for teaching and research. Mol Ecol Notes. 2006;6:288-95.

Pilgrim RLC, Palma RL. A list of the chewing lice (Insecta: Mallophaga) from birds in New Zealand. Notornis. 1982;29(Suppl):1-32.

Potts TH. Notes on a new species of Apteryx (A haastii, Potts). Trans Proc N Z Instit. 1872;4:204-5.

Pritchard JK, Stephens M, Donnelly P. Inference of population structure using multilocus genotype data. Genetics. 2000;155:945-59.

Ramasamy RK, Ramasamy S, Bindroo BB, Naik VG. STRUCTURE PLOT: a program for drawing elegant STRUCTURE bar plots in user friendly interface. Springerplus. 2014;3:431.

Rambaut A, Drummond AJ, Xie D, Baele G, Suchard MA. Posterior summarisation in Bayesian phylogenetics using Tracer 1.7. Syst Biol. 2018:67:901-4.

Ramstad KM, Dunning LT. Population genomic advances and opportunities in conservation of kiwi (Apteryx spp). In: Hohenlohe PA, Rajora OP, editors. Population genomics: wildlife. Cham: Springer; 2020. p. 493-521.

Ramstad KM, Pfunder M, Robertson HA, Colbourne RM, Allendorf FW, Daugherty $\mathrm{CH}$. Fourteen microsatellite loci cross-amplify in all five kiwi species
(Apteryx spp.) and reveal extremely low genetic variation in little spotted kiwi (A. owenii). Conserv Genet Resour. 2010;2:333-6.

Ramstad KM, Colbourne RM, Robertson HA, Allendorf FW, Daugherty CH. Genetic consequences of a century of protection: serial founder events and survival of the little spotted kiwi (Apteryx owenii). Proc R Soc b. 2013;280:20130576

Ramstad KM, Gibb GC, Robertson HA, Colbourne RM, Doran EE, Shepherd LD. Recent extinctions among Little Spotted Kiwi (Apteryx owenii) and the origin of extant populations. Emu. 2021. https://doi.org/10.1080/01584 197.2020.1840926.

Randler C. Avian hybridization, mixed pairing and female choice. Anim Behav. 2002;63:103-19.

Ride WDL, Cogger HG, Dupuis C, Kraus O, Minelli A. International code of zoological nomenclature. 4th ed. London: International Trust for Zoological Nomenclature; 1999.

Robertson HA, Colbourne RM. Survival of little spotted kiwi (Apteryx owenii) on Kapiti Island. Notornis. 2004;51:161-3.

Ronquist F, Teslenko M, var der Mark P, Ayres DL, Darling A, Höhna S, et al. MrBayes 32: efficient Bayesian phylogenetic inference and model choice across a large model space. Syst Biol. 2012:61:539-42.

Schaid DJ. Linkage disequilibrium testing when linkage phase is unknown. Genetics. 2004;166:505-12.

Scofield RP. Clarification of the status of the type specimens of Apteryx haastii Potts 1872, the great spotted kiwi. Notornis. 2004:51:152-4.

Shepherd LD, Lambert DM. Nuclear microsatellite DNA markers for New Zealand kiwi (Apteryx spp.). Mol Ecol Notes. 2006;6:227-9.

Shepherd LD, Lambert DM. Ancient DNA and conservation: lessons from the five species of endangered kiwi of New Zealand. Mol Ecol. 2008:17:2174-84

Shepherd LD, Worthy TH, Tennyson AJD, Scofield RP, Ramstad KM, Lambert DM. Ancient DNA analyses reveal contrasting phylogeographic patterns amongst kiwi (Apteryx spp.) and a recently extinct lineage of spotted kiwi. PLOS ONE. 2012;7:e42384.

Smouse PE, Peakall R. Spatial autocorrelation analysis of individual multiallele and multilocus genetic structure. Heredity. 1999;82:561-73.

Tennyson AJD, Palma RL, Robertson HA, Worthy TH, Gill BJ. A new species of kiwi (Aves, Apterygiformes) from Okarito. N Z Rec Auckland Mus. 2003:40:55-64.

Todesco M, Pascual MA, Owens GL, Ostevik KL, Moyers BT, Hübner S, et al. Hybridization and extinction. Evol Appl. 2016;9:892-908.

Undin M, Lockhart PJ, Hills SFK, Castro I. Genetic rescue and the plight of Ponui hybrids. Front Conserv Sci. 2021;1:622191.

van Oosterhout C, Hutchinson WF, Wills DP, Shipley P. MICRO-CHECKER: software for identifying and correcting genotyping errors in microsatellite data. Mol Ecol Notes. 2004;4:535-8.

Weir BS. Genetic data analysis II. Sinauer: Sunderland; 1996.

Weir JT, Haddrath O, Robertson HA, Colbourne RM, Baker AJ. Explosive ice age diversification of kiwi. Proc Natl Acad Sci USA. 2016;113:E5580-7.

Wirtz P. Mother species-father species: unidirectional hybridization in animals with female choice. Anim Behav. 1999;58:1-12.

Yonezawa T, Segawa T, Mori H, Campos PF, Hongoh Y, Endo H, et al. Phylogenomics and morphology of extinct paleognaths reveal the origin and evolution of the ratites. Curr Biol. 2017;27:68-77.

Ready to submit your research? Choose BMC and benefit from

- fast, convenient online submission

- thorough peer review by experienced researchers in your field

- rapid publication on acceptance

- support for research data, including large and complex data types

- gold Open Access which fosters wider collaboration and increased citations

- maximum visibility for your research: over 100M website views per year

At $\mathrm{BMC}$, research is always in progress.

Learn more biomedcentral.com/submissions 